2. To: (Receiving Organization)

Distribution

5. Proj./Prog./Dept./Div.:

RPP Corrosion Probe

8. Originator Remarks:

This document satisfies the requirements of Milestone A.3-1 of FY 2000 TTP\# RL09WT41.

11. Recelver Remarks:
Design of integrated corrosion monitoring station

3. From: (Originating Organization)

Equipment Engineering

6. Design Authority/Design Agent/Aeg. Engr:

EC Norman
4. Related EDT No::

$\mathrm{N} / \mathrm{A}$

7. Purchase Order No.:

$\mathrm{N} / \mathrm{A}$

9. Equip./Component No.:

$\mathrm{N} / \mathrm{A}$

10. System/BIdg./Facility:

$\mathrm{N} / \mathrm{A}$

12. Major Assm. Dwg. No.

$\mathrm{N} / \mathrm{A}$

13. Permiz/Permit Application No.:

$\mathrm{N} / \mathrm{A}$

14. Required Response Date:

$\mathrm{N} / \mathrm{A}$

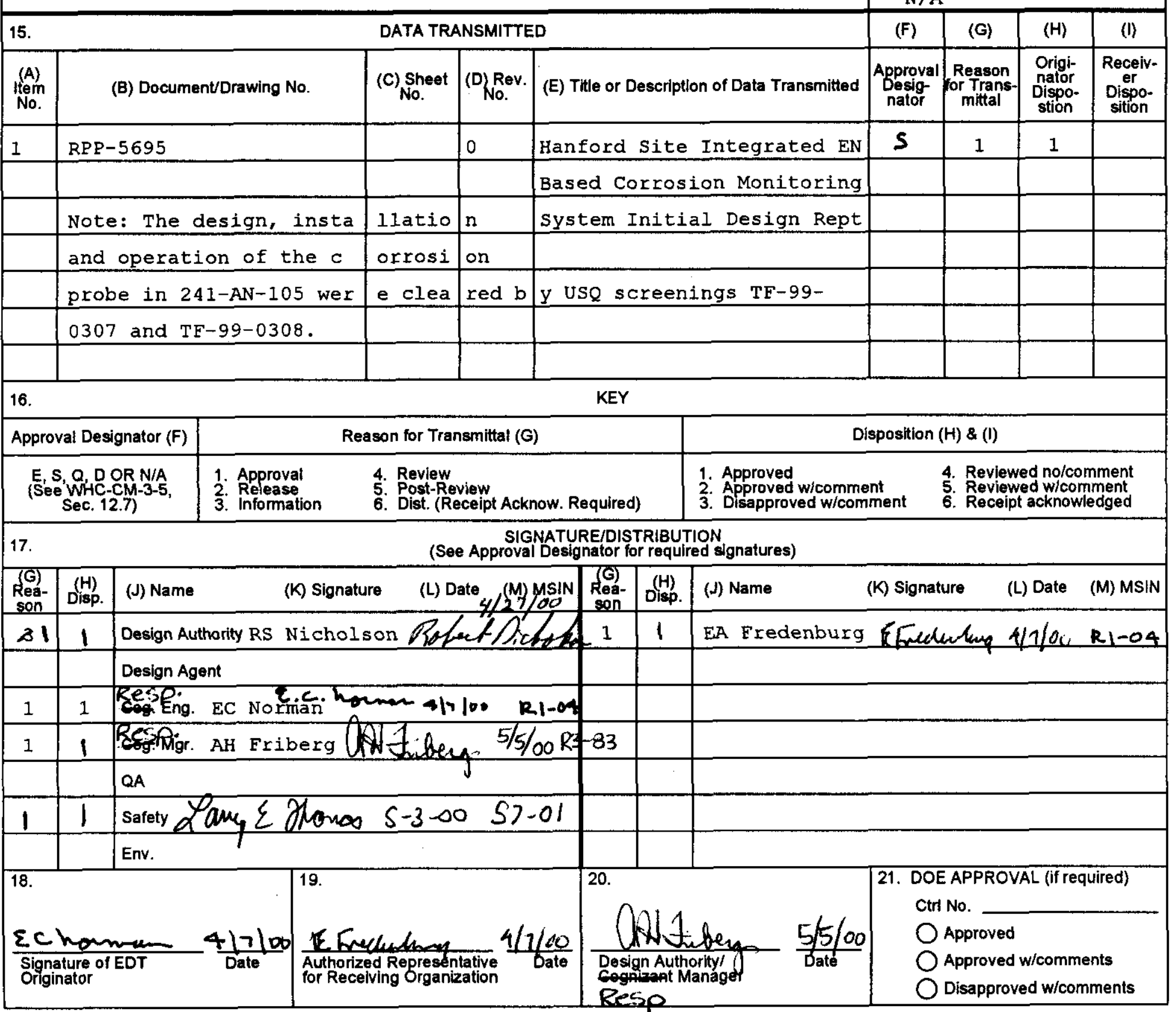




\title{
Hanford Site Integrated EN Based Corrosion Monitoring System Initial Design Report
}

\author{
E. C. Norman
}

CH2M HILL Hanford Group, Inc.

Richland, WA 99352

U.S. Department of Energy Contract DE-AC06-99RL14047

\author{
EDT/ECN: $628100 \quad$ UC: 2030 \\ Cost Center: $74700 \quad$ Charge Code: 112671 \\ B\&R Code: EW4010000 Total Pages: 11
}

Key Words: corrosion probe, multi-function probe, electrochemical noise, data analysis

Abstract: Design of integrated corrosion monitoring station.

This document meets the requirements of TTP RIO-9-WT-41 Milestone A.3-1.

TRADEMARK DISCLAIMER. Reference herein to any specific commercial product, process, or service by trade name, trademark, manufacturer, or otherwise, does not necessarily constitute or imply its endorsement, recommendation, or favoring by the United States Government or any agency thereof or its contractors or subcontractors.

Printed in the United States of America. To obtain copies of this document, contact: Document Control Services, P.O. Box 950, Mailstop H6-08, Richland WA 99352, Phone (509) 372-2420; Fax (509) 376-4989.

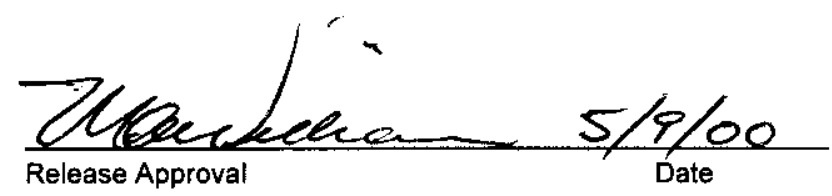

Approved For Public Release

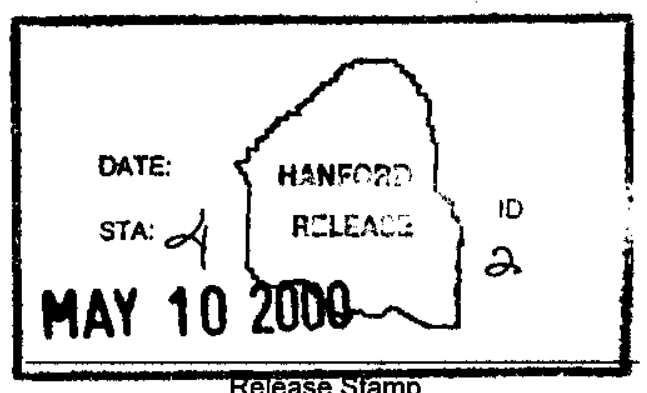

Release Stamp 
RPP-5695, Rev. 0

Hanford Site Integrated EN Based Corrosion Monitoring System Initial Design Report

\author{
G. L. Edgemon \\ Hiline Engineering and Fabrication, Inc. \\ 2105 Aviator Drive \\ Richland, Washington 99352
}




\section{Introduction and Background}

The Hanford Site has 177 underground waste tanks that store approximately 253 million liters of radioactive waste from 50 years of plutonium production [1-4]. Tank waste is in liquid, solid, and sludge forms. Tanks also contain a vapor space above the solid and liquid waste regions. Leaks began to appear in the single-shell tanks shortly after the introduction of nitrate-based wastes in the 1950s. Leaks are now confirmed or suspected to be present in a significant number of single-shell tanks [1]. The probable modes of corrosion failures are reported as nitrate stress corrosion cracking (SCC) and pitting [2]. No leaks have been recorded in the Hanford Site's double-shell tanks (DSTs). A new program is being developed to upgrade the site's current corrosion monitoring strategy for DSTs.

Previous efforts to monitor internal corrosion of waste tank systems at Hanford and other DOE sites have included linear polarization resistance (LPR) and electrical resistance techniques [5-6]. These techniques are most effective for monitoring uniform corrosion, but are not well suited for the detection of localized corrosion (pitting and SCC). A two year laboratory study was started at Hanford in 1995 to provide a technical basis for using electrochemical noise (EN) based corrosion monitoring systems for monitoring corrosion in Hanford nuclear waste tanks [7]. Based on this study, a prototype system was constructed and deployed in DST 241-AZ-101 in August, 1996 [8]. Based on the successful demonstration of this prototype for more than a year, a first-generation full-scale system was designed and installed into DST 241-AN-107 in September 1997 [9]. A second-generation full-scale system similar to the 241-AN-107 system was designed, fabricated and installed in DST 241-AN-102 in August 1998 [10]. A thirdgeneration full-scale system was deployed into DST 241-AN-105 in January 2000 [11].

All four of Hanford's EN based corrosion-monitoring systems measure instantaneous fluctuations in corrosion current and potential between sets of three nominally identical mild steel electrodes (a working, a counter, and a pseudo-reference electrode) positioned on instrument trees within the waste tanks. The fluctuations in current and potential are caused by corrosion of the electrodes. It has been shown that each type of corrosion phenomenon presents a unique relationship between corrosion current and potential transients in the temporal data [12$30]$.

Milestone Numbers A.3-1 and A.3-2 of TTP RL0-9-WT-41 demand that several of Hanford's corrosion monitoring systems be tied together for operation from a single location. This report documents the general design of Hanford's corrosion monitoring systems and how they will be tied together into a new integrated corrosion monitoring station.

\section{In-Tank Instrument Tree Design}

Hanford's corrosion monitoring systems are formed from two basic parts: the in-tank instrument tree and the ex-tank instrumentation. The in-tank instrument trees used to deploy corrosion monitoring electrodes into each of the instrumented tanks are similar in design. General design features are as follows: 
- The probe is fabricated from materials capable of providing at least five years of service. Typically this is 304/304L dual rated stainless steel.

- The probe is designed to fit through a $10.2-\mathrm{cm}$ (4.0 in.) diameter riser.

- The probe design facilitates decontamination by minimizing areas of liquid retention.

- All materials are capable of withstanding temperature ranges up to $100^{\circ} \mathrm{C}$.

- All materials are capable of withstanding liquid phase $\mathrm{pH}$ ranges from 7 to 14 .

- All materials are capable of withstanding radiation levels up to $1000 \mathrm{R} / \mathrm{hr}$.

- Conductor/feed-through connections are angled to withstand probe flexure.

- Probe incorporates eight channels of EN electrodes plus other equipment depending on tank riser selected for installation. Other pieces of equipment incorporated on some or all of Hanford's systems include thermocouples, strain gauges, pressure ports, gas sampling ports, and high-level detectors.

- Systems are designed to collect EN data on four channels of C-ring type electrodes.

- One electrode of each C-ring array is pre-cracked and strained prior to immersion.

- Systems are designed to collect EN data on four channels of bullet shaped electrodes.

- EN electrodes are fabricated from archived ASTM A-537 CL 1 mild steel.

- Electrodes are electrically isolated from probe through the use of glass-lined feed throughs and radiation resistant EPDM O-ring gaskets.

- Probe body serves as grounded shield to reduce unwanted interference in the data.

The tank-intrusive portion of the system is manufactured by Hiline Engineering and Fabrication in Richland, Washington and has passed Hanford site structural analysis and seismic analysis for non-safety class equipment $[31,32]$.

\section{Data Collection}

The following are the primary design features of the software/hardware used to collect data from the tank-intrusive portion of the probe:

- Current and voltage EN data is collected in an automated, user configurable fashion.

- Data are recorded at a rate of one measurement per second.

- Systems simultaneously monitor eight channels of EN electrodes.

- Systems are capable of periodically conducting LPR scans at user-configurable intervals.

- Systems are housed in climate controlled enclosures close to riser used for deployment.

- Systems use Hanford Local Area Network (LAN) to transmit data for analysis.

- Systems can be operated with commercial remote access software.

- Above ground wiring uses driven shields to reduce external electrostatic noise in the data.

- MTL Model 755-AC shunt-diode type intrinsic safety barriers are used on all conductors.

- The operating software is compatible with site standard desktop PCs.

- All data is stored in ODBC and SQL compatible databases.

The data collection hardware is manufactured by Petroleum Research Products (PRP), Ltd. The data collecton software is an Amulet system produced by Corrosion \& Condition Control, Ltd. The design of the corrosion monitoring system has been reviewed by the Hanford Site 
Flammable Gas Equipment Advisory Board and is bounded by report FGEAB-97-040, Rev. 2 [33].

\section{Existing System Designs}

Currently the corrosion monitoring systems associated with tanks 241-AN-102, 241-AN-105, and 241-AN-107 are each configured differently and housed in different areas of the 200E tank farms at the Hanford Site.

\section{1-AN-102 System}

Figure 1 shows the existing configuration of the $241-\mathrm{AN}-102$ system. The in-tank portion of the 241-AN-102 corrosion probe is housed in riser 241-AN-102-WST-RISER-016 of DST 241-AN102.

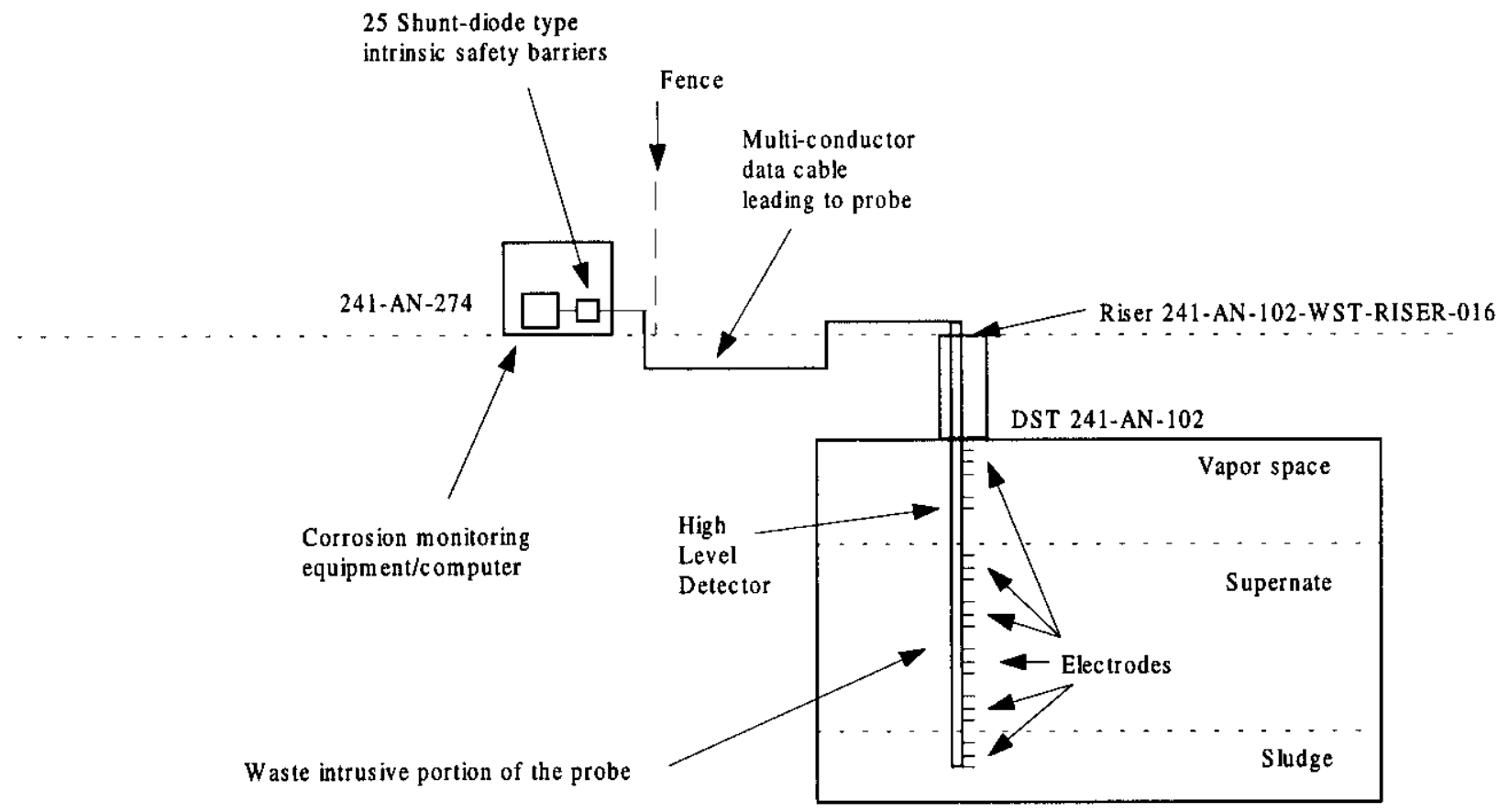

Figure 1: As-built configuration of the 241-AN-102 corrosion monitoring system

Belden 1061A data cable is used to transmit data from the in-tank probe to the data collection hardware. The data cable extends from the top of the corrosion probe approximately 300 feet into the 241-AN-274 caustic addition building where it passes through MTL Model 755 AC intrinsic safety barriers before final termination in the PRP corrosion monitoring hardware. No connection was made to the Hanford LAN at the time of installation due to budgetary restrictions. Data collected from this system must currently be manually downloaded and carried to a separate computer for analysis. 
Figure 2 shows the existing 241-AN-105 corrosion monitoring system. The in-tank portion of the 241-AN-105 corrosion probe is housed in riser 241-AN-105-WST-RISER-016 of DST 241AN-105.

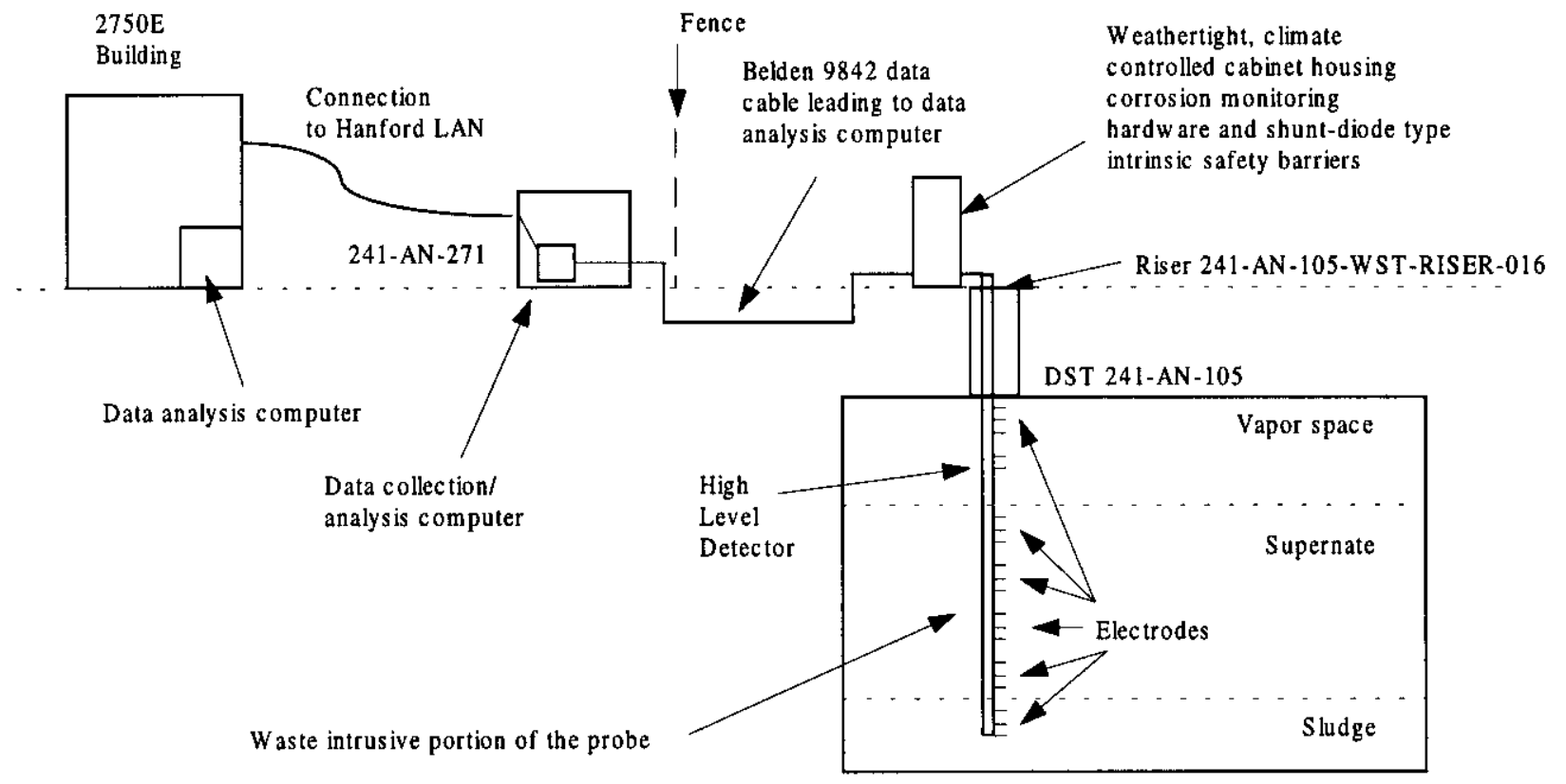

Figure 2: As-built configuration of the 241-AN-105 corrosion monitoring system

Belden 8178 data cable is used to transmit data from the in-tank probe to the data collection hardware. The data cable extends from the top of the corrosion probe approximately 10 feet into a climate-controlled weather-tight enclosure mounted adjacent to the riser. The data cable then passes through MTL Model 755 AC intrinsic safety barriers before final termination in the PRP corrosion monitoring hardware. The data signal is digitalized by the PRP equipment and transmitted through Belden 9842 cable approximately 500 feet into a data analysis computer housed in the 241-AN-271 instrument building. The data analysis computer is connected to the Hanford LAN through an Asymmetric Digital Subscriber Line (ADSL). Data can be analyzed remotely from any computer connected to the Hanford LAN

\section{1-AN-107 System}

Figure 3 shows the existing 241-AN-107 corrosion monitoring system. The in-tank portion of the 241-AN-107 corrosion probe is housed in riser 241-AN-107-WST-RISER-016 of DST 241AN-107. Belden 1220B data cable is used to transmit data from the in-tank probe to the data collection hardware. The data cable extends from the top of the corrosion probe into Model MTL $755 \mathrm{AC}$ intrinsic safety barriers then runs approximately 500 feet into the 241-AN-271 instrument building where it terminates at corrosion monitoring hardware manufactured by Capcis March Ltd (CML). 
RPP-5695, Rev. 0

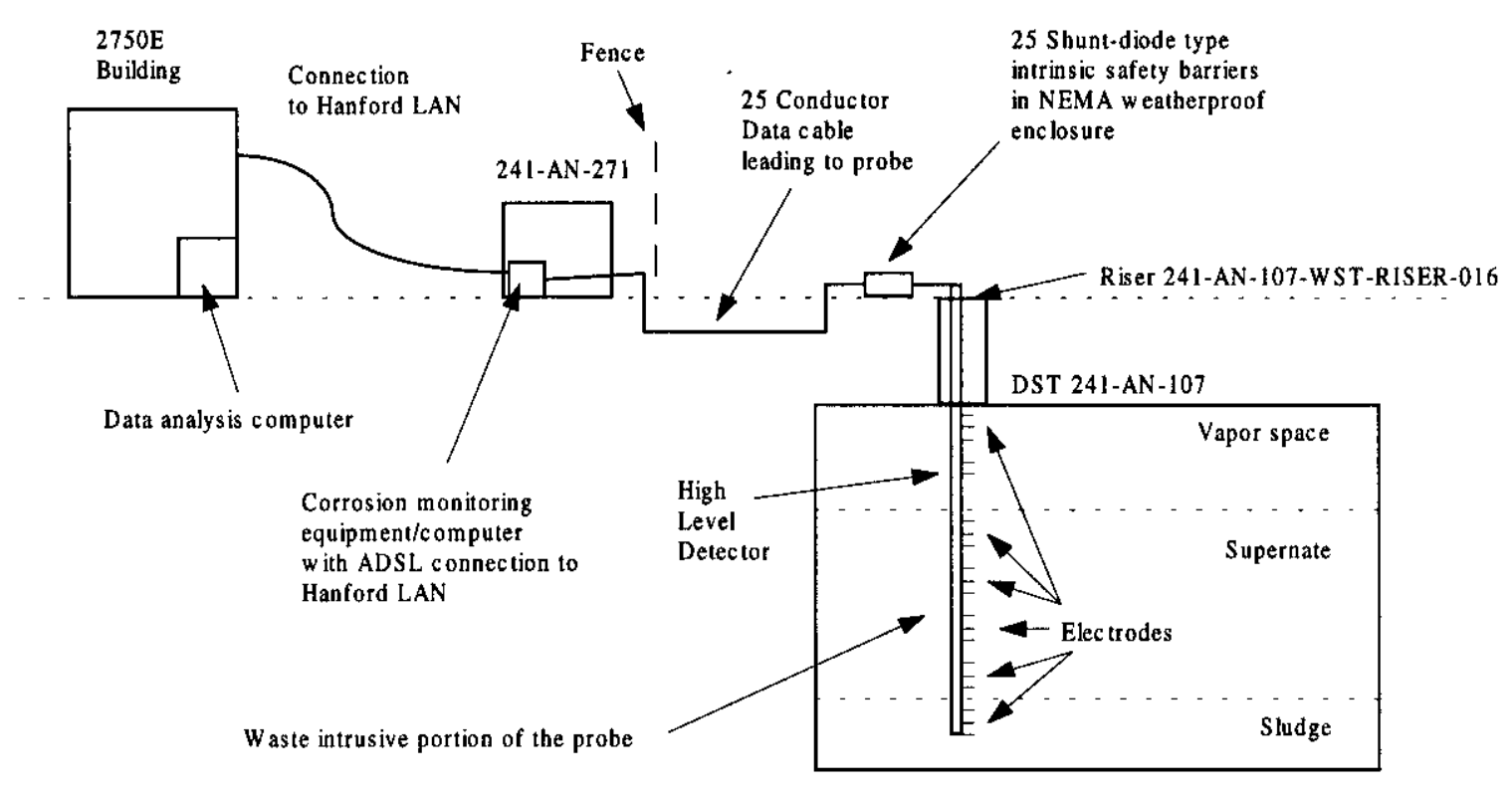

Figure 3: As-built configuration of the 241-AN-107 corrosion monitoring system

The CML hardware is connected to the data analysis computer with an IEEE 488 cable. The data analysis computer is connected through an ADSL to the Hanford LAN. Data can be analyzed remotely from any computer connected to the Hanford LAN.

\section{Integrated System Design}

The integrated system will be physically located in the 241-AN-271 instrument building and will house the 241-AN-102, 241-AN-105, 241-AN-107 corrosion monitoring systems plus any future systems to be installed in 241-AN farm. The system is comprised of indoor cabinetry, data collection computers, corrosion monitoring equipment, and cabling to tie the remote systems to the Hanford LAN. This system is designed to meet the requirements of Milestone Numbers A.31 and A.3-2 of TTP RL0-9-WT-41. Once installed, this system will provide a centralized data analysis and control station for all tanks instrumented for corrosion monitoring in the $200 \mathrm{E}$ area tank farms.

Since the configuration of each of the existing corrosion monitoring systems currently installed in 241-AN-102, 241-AN-105, and 241-AN-107 is somewhat different, different pieces of equipment will be installed for each system in the final integrated cabinet. Based on the performance of the 241-AN-105, the 241-AN-102 and 241-AN-107 systems plus any future systems may be upgraded to match the configuration of the 241-AN-105 equipment. The design of the integrated system will allow for such upgrades. 
The 241-AN-271 instrument building will serve as the centralized location for the corrosion monitoring systems operating or planned for operation in the $200 \mathrm{E}$ area tank farms. A dedicated Rittal Model PC-4603-703 instrument cabinet will be permanently installed in this building to house the instrumentation associated with these systems. Specific pieces of equipment to be installed in the cabinet include four Dell Optiplex GX-1 computers for data collection and analysis, the PRP corrosion monitoring hardware for tanks 241-AN-102 and 241-AN-107, a MultiSync 15" computer monitor, Blackbox switch gear (part numbers SW-722A-R3, EHN-0510005, and EHN-054-0005), a SmartPro model SMART700RM uninterupted power supply (UPS), an Allied Telesyn eight-port unmanaged 10Base-T Hub (model AT-MR820TR) AUI/BNC/UTP uplink to tie the computers into a single ADSL, and the Westel ADSL equipment (ATU-C Part \# A90-320504EB and ATU-R Part \# A99-FC2RT-RT1000) to tie the field computers to the Hanford LAN. Pending the succesful demonstration of the 241-AN-105 system, the PRP hardware for 241-AN-102 and 241-AN-107 located in the integrated system cabinet will be removed and relocated in separate enclosures by the appropriate risers in the

field. The control/data collection computers for these two systems will remain in the integrated system cabinet.

\section{Summary and Conclusions}

Milestone Numbers A.3-1 and A.3-2 of TTP RL0-9-WT-41 demand that several of Hanford's corrosion monitoring systems be tied together for operation from a single location. Primary design features of this new integrated system are as follows:

- Existing EN based corrosion monitoring systems currently operating in DSTs 241-AN102 and 241-AN-107 will be controlled from the new integrated system cabinet.

- The new EN based system installed in 241-AN-105 will be controlled from the new integrated system cabinet.

- Future corrosion monitoring systems in the 241-AN farm will be controlled from the new integrated system cabinet.

- The current configurations of the 241-AN-102 and 241-AN-107 systems are different from the 241-AN-105 system. If the 241-AN-105 system outperforms the 241-AN-102 and 241-AN-107 systems, the 241-AN-102 and 241-AN-107 systems will be upgraded to match the 241-AN-105 system design. The new integrated system design will facilitate these configuration changes.

- At the conclusion of install, all systems will utilize the same corrosion monitoring hardware manufactured by PRP Ltd. and the same software manufactured by Corrosion \& Condition Control, Ltd.

- All corrosion monitoring system housed in the integrated system cabinet will be tied to the Hanford LAN through the use of commercially available ethernet and ADSL equipment.

\section{References}

[1] P.C. Ohl, J.D. Thomson, and F.R. Vollert, Corrosion Considerations for Life Management of Hanford High Level Waste Tanks, CORROSION/94, paper no. 142, (Houston, TX: NACE International, 1994). 
[2] D.C. Lini, Compilation of Hanford Corrosion Studies, Atlantic Richfield Hanford Company Report, ARH-ST-111, UC-70, July, 1975.

[3] J.R. Divine, W.M. Bowen, D.B. Mackey, D.J. Bates, and, K.H. Pool, Prediction Equations for Corrosion Rates of A537 and A516 Steels in Double Shell Slurry, Future PUREX, and Hanford Facilities Wastes, Pacific Northwest Laboratory Report, PNL5488, June, 1985.

[4] W.C Carlos, Recommendations for Erosion/Corrosion Allowance for Multi-Function Waste Tank Facility Tanks, CORROSION/95, paper no. 449, (Houston, TX: NACE International, 1995).

[5] J.L. Nelson, Hanford DST Corrosion Monitoring Instrument Tree, CORROSION/95, paper no. 440, (Houston, TX: NACE International, 1995).

[6] R.K. Shukla, A.J. Perkins, P.M. Bourgeois, R.J. Jaramins, W.G. Secen, and, D.J. Stroud, Corrosion Monitoring of High Level Waste Storage Tank 8-D2 at the West Valley Demonstration Project, CORROSION/94, paper no. 121, (Houston, TX: NACE International, 1994).

[7] G.L. Edgemon and G.E.C. Bell, Technical Basis for Electrochemical Noise Based Corrosion Monitoring of Underground Nuclear Waste Storage Tanks, Westinghouse Hanford Company Report, WHC-SD-WM-TI-772, November, 1996.

[8] G.L. Edgemon, J.L. Nelson, P.C. Ohl, and G.E.C. Bell, Hanford Prototype Corrosion Probe Operational Experience, CORROSION/97, paper no. 97124, (Houston, TX: NACE International, 1997).

[9] G.L. Edgemon, J.L. Nelson, and G.E.C. Bell, Design of an Electrochemical Noise Based Corrosion Monitoring Probe for High Level Nuclear Waste Storage Tanks, CORROSION/98, paper no. 98175, (Houston, TX: NACE International, 1998).

[10] G.L. Edgemon and J. L. Nelson, Design of Second-Generation Corrosion Monitoring Probe, Lockheed Martin Hanford Company Report, HNF-2517, Rev. 0, April, 1998.

[11] G.L. Edgemon, Design of Multi-Function Hanford Tank Corrosion Monitoring System, Lockheed Martin Hanford Company Report, HNF-4285, Rev. 0, April, 1999.

[12] T. Haygard and J. R. Williams, Trans. Farad. Soc. 57, (1961): p. 2288.

[13] P. Bindra, et al., Discussions of Faraday Soc. 56, (1974): p. 189.

[14] M. Fleischmann, et al., Surface Science 100-101, (1980): p. 583.

[15] G.J. Bignold and M. Fleischmann, Electrochemical Acta 19, (1974): p. 363. 
[16] E. Budevski, et al., Electrochemical Acta 28, (1983): p. 925.

[17] G. Blanc, et al., Electrochemical Acta 23, (1978): p. 337.

[18] K. Hladky and J. L. Dawson, Corrosion Science 22, (1982): p. 231.

[19] D.A. Eden, J.L. Dawson, and D.G. John, U.K. Patent Application 861158, May 1986, U.S. Patent 5139627.

[20] K. Hladky, European Patent 084404A3, U.S. Patent 455709, Canadian Patent 418938.

[21] U. Bertocci, Electrochemical Noise Analysis and Its Application to Corrosion, CORROSION/89, paper no. 24, (Houston, TX: NACE International, 1989).

[22] J.L. Dawson, D.M. Farrell, P.J. Aylott, and K. Hladky, Corrosion Monitoring Using Electrochemical Noise Measurements, CORROSION/89, paper no. 31, (Houston, TX: NACE International, 1989).

[23] D.A. Eden, A. N. Rothwell, and J.L. Dawson, "Electrochemical Noise for Detection of Susceptibility to Stress Corrosion Cracking, CORROSION/91, paper no. 444, (Houston, TX: NACE International, 1991).

[24] D.M. Farrell, Industrial Corrosion 9, (1991): p. 7.

[25] A.N. Rothwell, T.G. Walsh, and W.M. Cox, On Line Corrosion Investigation and Surveillance - Chemical Plant Case Studies, CORROSION/91, paper no. 170, (Houston, TX: NACE International, 1991).

[26] J.L. Dawson, et al., On-line Monitoring of Continuous Process Plants, ed. D. Butcher, (Ellis Horwood, NY, 1983).

[27] D.M. Farrell, W.M. Cox, and D. Gearey, Multi-System Corrosion Monitoring in a Cyclic Reheat Test Facility; Phase 1, Electric Power Research Institute Report, CS-5776, 1988.

[28] D.M. Farrell, W.M. Cox and D. Gearey, Multi-System Corrosion Monitoring in FGD Systems; Phase 2, Electric Power Research Institute Report, CS-5734, 1988.

[29] B.C. Syrett and W.M. Cox, in: Proc. First Int. Symposium on Electrochemical Noise Measurements for Corrosion Applications, ASTM STP 1277, eds. J.R. Kearns, J.R. Scully, P.R. Roberge, D.L. Reichert, and J.L. Dawson, (American Society for Testing and Materials, Philadelphia, PA, 1996) p. 173.

[30] C.A. Lotto and R.A. Cottis, Corrosion 45, (1989): p. 136. 
[31] H. P. Shrivastava, Structural Evaluation of Second Generation Double Shell Tank Corrosion Probe Tree, Lockheed Martin Hanford Company Report, HNF-SD-WM-CN090, Rev. 0, June, 1997.

[32] H. S. Ziada, Analysis of the Effects of Corrosion Probe on Riser 241-AN-102-WST-16 During Seismic Event, Numatec Hanford Company Report, HNF-3162, Rev. 0, November, 1998.

[33] C. C. Scaief III, Flammable Gas Equipment Advisory Board Interpretation/ Recommendation Report - Corrosion Monitoring System, FGEAB-97-040. Rev. 2, Lockheed Martin Hanford Corporation, May, 1998. 


\section{DISTRIBUTION SHEET}

To

Distribution

Project Title/Work Order

Hanford Site Integrated EN Based Corrosion Monitoring System Initial Design Report

Name

EA Fredenburg

EC Norman

RS Nicholson
Equipment Engineering
From
Page 1 of 1

Date April 27, 2000

EDT No. 628100

ECN No.

\begin{tabular}{|c|c|l|c|c|} 
MSIN & $\begin{array}{c}\text { Text } \\
\text { With All } \\
\text { Attach. }\end{array}$ & Text Only & $\begin{array}{c}\text { Attach./ } \\
\text { Appendix } \\
\text { Only }\end{array}$ & $\begin{array}{c}\text { EDT/ECN } \\
\text { Only }\end{array}$ \\
\hline R1-04 & $\mathrm{x}$ & & & \\
\hline $51-04$ & $\mathrm{x}$ & & & \\
\hline $5-05$ & $\mathrm{x}$ & & & \\
\hline
\end{tabular}

